\title{
Dedolomitization Potential of Fluids from Gypsum-to-Anhydrite Conversion: Mass Balance Constraints from the Late Permian Zechstein-2-Carbonates in NW Germany
}

\author{
M. Hallenberger $\mathbb{D}^{1},{ }^{1}$ L. Reuning, ${ }^{1}$ and J. Schoenherr ${ }^{2}$ \\ ${ }^{1}$ Energy and Mineral Resources Group (EMR), Geological Institute, RWTH Aachen University, Aachen, Germany \\ ${ }^{2}$ ExxonMobil Production Deutschland GmbH (EMPG), Hannover, Germany \\ Correspondence should be addressed to M. Hallenberger; maximilian.hallenberger@emr.rwth-aachen.de
}

Received 16 November 2017; Accepted 10 January 2018; Published 18 February 2018

Academic Editor: Andri Stefansson

Copyright (c) 2018 M. Hallenberger et al. This is an open access article distributed under the Creative Commons Attribution License, which permits unrestricted use, distribution, and reproduction in any medium, provided the original work is properly cited.

\begin{abstract}
The Zechstein-2-Carbonates represent one of the most prolific hydrocarbon systems of Central Europe. Carbonate reservoir quality is primarily controlled by mineralogy, with dolomite representing moderate-to-good porosities and calcite commonly representing low porosities. Current models suggest that this calcite is the result of a basin-wide phase of dedolomitization. The calcium (Ca) source for the dedolomites is thought to be derived from the fluids liberated during gypsum-to-anhydrite conversion. We present an easy-to-use and generally applicable template to estimate the dedolomitization potential of these fluids. Depending on reaction stoichiometry, salinity, and temperature, we estimate that between $2.8 * 10^{-3} \mathrm{~m}^{3}$ and $6.2 * 10^{-3} \mathrm{~m}^{3}$ of calcite may replace dolomite for each $\mathrm{m}^{3}$ of anhydrite created. Within the constraints dictated by the environment of the late Permian Zechstein basin, we estimate that about $5 * 10^{-3} \mathrm{~m}^{3}$ of dedolomite is created for each $\mathrm{m}^{3}$ of anhydrite. Mass balance constraints indicate that fluids derived from gypsum-to-anhydrite conversion account for less than $1 \%$ of the observed dedolomite in most of the studied industry wells from northern Germany.
\end{abstract}

\section{Introduction}

The Zechstein-2-Carbonate (Ca2) of the Southern Permian Basin represents one of the major gas plays in northern Germany. Reservoir quality is mainly controlled by mineralogy. Where the mineralogy is dominated by dolomite, reservoir quality is predicted to be moderate to good and poor where the mineralogy is mainly calcitic [1-3]. Early studies suggested that the vast majority of this calcite is not of primary origin but rather formed due to dedolomitization $[4,5]$.

Dedolomitization or dolomite calcitisation describes the replacement process of dolomite by calcite [6]. The general reaction for dedolomitization can be written as follows:

$$
\mathrm{CaMg}\left(\mathrm{CO}_{3}\right)_{2}+\mathrm{Ca}^{2+}=2 \mathrm{CaCO}_{3}+\mathrm{Mg}^{2+}
$$

Dolomite dissolves and calcite precipitates. This process consumes calcium and liberates magnesium [7]. Several conditions have to be met for dedolomitization to take place. A low $\mathrm{Mg}^{2+}$ to $\mathrm{Ca}^{2+}$ ratio of the pore fluid is necessary, so that dolomite is undersaturated and calcite is oversaturated. Once dedolomitization starts the liberated $\mathrm{Mg}^{2+}$ has to be transported by a steady fluid flow. Otherwise the $\mathrm{Mg}^{2+} / \mathrm{Ca}^{2+}$ ratio increases and dedolomitization ceases [8]. While small amounts of $\mathrm{CO}_{2}$ are necessary to bring dolomite into solution [9], a high $\mathrm{CO}_{2}$ partial pressure inhibits dedolomitization due to calcite being also undersaturated $\left(\mathrm{pCO}_{2} \ll 0.5 \mathrm{~atm}\right.$, de Groot [8]). Instead of calcite precipitation, dissolutionrelated secondary porosity is created. An early experimental study by de Groot (1967) further concluded that dedolomite may only form at temperatures lower than $50^{\circ} \mathrm{C}$. This led to the general assumption that dedolomite is related to nearsurface processes, either linked to ancient paleosurfaces or linked to a phase of late surface weathering $[10,11]$. Since then, several studies have found that dedolomitization takes place in a wide range of diagenetic settings, including shallow 
to deep burial [12-15]. Escorcia et al. [16] concluded that temperatures above $50^{\circ} \mathrm{C}$ may slow down dedolomitization rather than fully stopping it.

Due to the specific conditions under which dedolomite forms, it commonly occurs either connected to meteoric exposure surfaces or connected to enhanced fluid conduits such as faults and fractures $[17,18]$. In contrast, dedolomites with similar macro- and microfabrics have been described in other parts of the Southern Permian Basin from timeequivalent Zechstein-2-Carbonates, ranging from eastern Poland to the NE coast of England, sometimes affecting carbonate with hundreds of meters of thickness [2, 3, 9, 19-23].

The majority of the Ca2 dedolomite reported in Germany $[9,24-26]$, the Netherlands [21, 27], and Poland [28] is linked to burial. This interpretation is based on isotope data [9], which shows slight shifts in $\delta^{18} \mathrm{O}$ relative to dolomite, elevated fluid inclusion temperatures of dedolomite $[19,28]$, and the absence of any signs of meteoric exposure after initial dolomitization $[9,25]$.

The $\mathrm{CO}_{2}$, which is responsible for dedolomitization within the $\mathrm{Ca} 2$, is thought to be internally sourced [9]. The organic material, which is mostly present in the basin and lower slope facies, was subjected to thermal degradation and thereby released $\mathrm{CO}_{2}$. The total organic carbon (TOC) of basin and lower slope is usually smaller than $1 \%$ with an average of $0.54 \%$ [29]. The thermal conversion takes place during the early stages of thermal organic matter maturation [30]. The $\mathrm{CO}_{2}$ then migrated upslope and initiated dedolomitization (Figure 1). Dissolution of dolomite also took place and led to local creation of secondary porosity, especially in the lower slope facies $[9,27]$. In this model the origin as well as the migration path of the $\mathrm{CO}_{2}$ explains the spatial distribution of dedolomite within the Zechstein-2Carbonates. Dedolomitization was most effective within the basin facies, which was nearly completely calcified. Towards the platform, the relative amount of dedolomite decreases gradually $[9,23]$. Largest absolute amounts of dedolomite can be found on the upper to middle slope, where the Ca2 achieves its largest thickness [27].

Following the initial proposal by Clark [9], calcium sources for the Zechstein dedolomites have been largely attributed to the fluids released during gypsum-to-anhydrite conversion of the over- and underlying anhydrite sequences (A2 and A1) [9, 21, 23, 27]. During this process the gypsum sequence loses $49 \%$ of its volume in the form of intercrystalline water [31,32]. These fluids are saturated with respect to $\mathrm{CaSO}_{4}$ [33]. The conversion reaction for this process is as follows:

$$
\mathrm{CaSO}_{4} \cdot 2 \mathrm{H}_{2} \mathrm{O}=\mathrm{CaSO}_{4}+2 \mathrm{H}_{2} \mathrm{O}
$$

Even though gypsum-to-anhydrite conversion fluids are thought to be the only source for dedolomitization of the Zechstein-2-Carbonates [9], there has been no attempt to estimate their actual dedolomitization potential. The goal of this research is to quantitatively test the conventional Ca2 dedolomitization model. This will be achieved through a combination of geochemical batch modelling and mass balance calculations. In a first step, we will estimate the

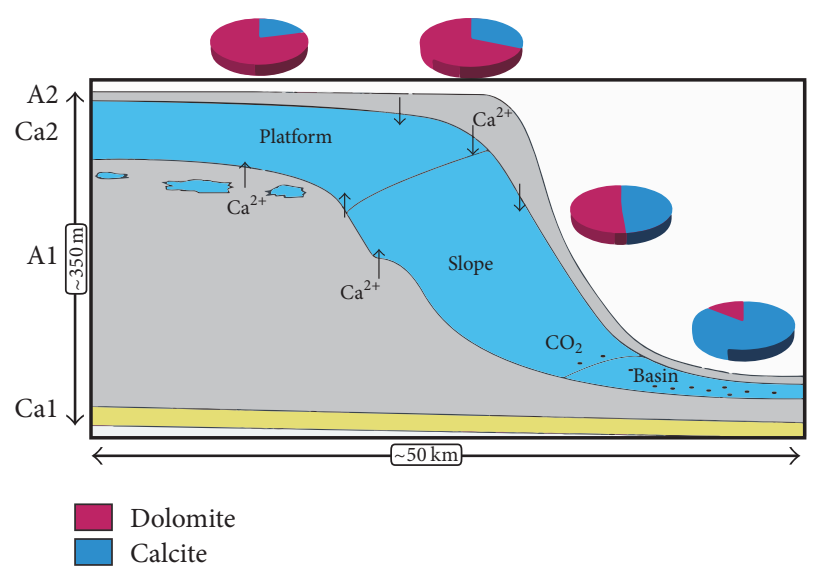

FIGURE 1: Dedolomitization model of the Zechstein-2-Carbonates as defined by Clark [9] (depositional model after Strohmenger et al. [1]). Dehydration of the over- and underlying gypsum deposits led to the large scale release and migration of calcium-rich fluids, as indicated by the black straight arrows. The $\mathrm{CO}_{2}$ which is needed to bring dolomite into solution is produced during organic matter maturation which primarily took place in the lower slope to basin facies. High amounts of $\mathrm{CO}_{2}$ lead to higher degrees of dedolomitization, explaining why basin to slope deposits show a higher degree of dedolomitization while the platform deposits are largely dolomitic. Pie charts displaying the distribution of calcite and dolomite for different depositional environments are chosen from representative wells within the study area.

dedolomitization potential of fluids expelled by the conversion of gypsum to $1 \mathrm{~m}^{3}$ of anhydrite. That is to say, how much dolomite can potentially be transformed into calcite when gypsum dehydrates to $1 \mathrm{~m}^{3}$ of anhydrite. Subsequently, we will use the Northern Germany Zechstein basin as a case study to test how much of the observed dedolomite can be explained by this process. The results of this study may have direct implications for dedolomitization processes in other carbonate evaporite successions worldwide.

\section{Geological Background}

The Zechstein-2-Carbonates, also known as the Stassfurt Carbonate or the Ca2, were deposited in Southern Permian Basin (SPB) which itself forms part of the Central European Basin System (CEBS) [37]. The CEBS ranges from the east coast of England to Poland (Polish Trough) and from Norway to the central parts of Germany $[38,39]$.

Due to the hot arid climate and the lowering of source areas at the end of the Lower Permian Rotliegend, subsidence began to outpace sedimentation, resulting in the development of a basin with elevations way below the sea level. The onset of rifting combined with a general rise in sea level then led to the flooding of the depression by the Boreal Sea, which also marks the beginning of Zechstein sedimentation [40].

Further flooding led to the cyclic precipitation of thick sequences of carbonates, sulfates, and salt. Traditionally four carbonate/claystone-evaporite cycles have been described in Germany, known as the Werra (Z1), Stassfurt (Z2), Leine 


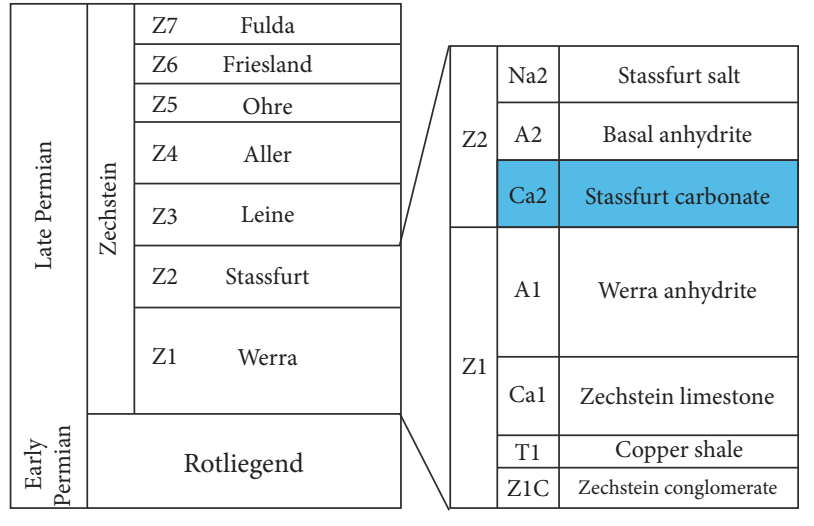

FIGURE 2: Simplified overview of the regional Zechstein stratigraphy of Germany (modified after Steinhoff and Strohmenger [34]).

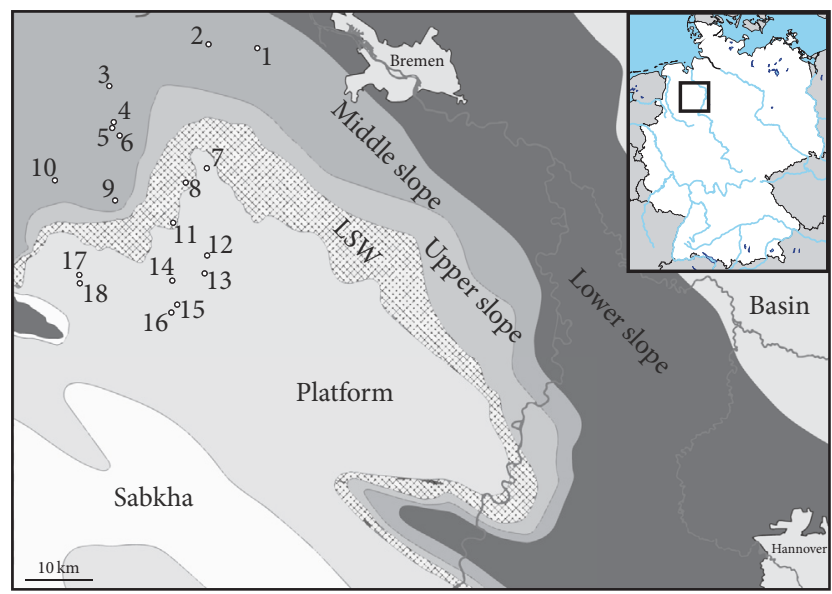

Figure 3: Paleogeography of the Zechstein-2-Carbonate for the study area in northern Germany. The map displays the studied wells and the uppermost facies association of the Stassfurt Carbonate (Ca2) within this area (modified after Strohmenger and Strauss [35]).

(Z3), and Aller (Z4) Series. More recently three additional cycles (Ohre Z5, Friesland Z6, and Fulda Z7) have been recognized in the axial parts of the Northern German Basin [28] (Figure 2).

Each cycle represents progressive evaporation with carbonates $(\mathrm{Ca})$ and/or siliciclastics at their base transitioning into anhydrites (A) and topped by thick sequences of salt (Na) and small amounts of potassium and magnesium salts $[1,39,41]$. The Stassfurt carbonates are therefore abbreviated with $\mathrm{Ca} 2$. The $\mathrm{Ca} 2$ overlies the Werra Anhydrite (A1) and is itself succeeded by the Basal Anhydrite (Figure 2).

The depositional environment of the $\mathrm{Ca} 2$, within the study area, ranges from lower slope to platform (Figure 3). The thickness ranges between 20 and $80 \mathrm{~m}$ for platform and 10 and $250 \mathrm{~m}$ for slope deposits, with decreasing thickness from upper to lower slope. The basinal facies is usually thinner than $10 \mathrm{~m}$. The overall trend in thickness and facies distribution is influenced by sea-level variations, tectonic subsidence, syndepositional tectonic, and the geometry of the underlying Werra Anhydrite [42]. Highest thicknesses are achieved within the upper slope, where the Ca2 directly overlies the former A1 slope [35].

\section{Materials and Methods}

The simulations include data from 18 industry wells situated southwest of Bremen in NW Germany, with each well drilled through the entirety of the $\mathrm{A} 2, \mathrm{Ca} 2$, and $\mathrm{A} 1$ providing a continuous and complete stratigraphic record. Calcite within the well-logs provided by ExxonMobil Production Deutschland GmbH (EMPG) was identified by reaction with hydrochloric acid $(\mathrm{HCl})$. Based on this observation we calculated the calcite-dolomite ratios which have been used for the presented model. Extensive petrographic evaluations have shown that the overwhelming majority of the calcite within the $\mathrm{Ca} 2$ displays textures which are typical for dedolomite $[2-5,9,19,20,25,43]$. Therefore, calcite is assumed to be a good proxy for total amount of dedolomite. The well data is furthermore thought to be an approximation of the cumulative thickness of dedolomite layers.

Chemical batch analysis was achieved with the geochemical modelling software PHREEQC [44]. All PHREEQC calculations are based on the Specific Ion Interaction Theory database (sit.dat) developed by the French National Radioactive Waste Management Agency (ANDRA). The sit database was selected due to its compatibility with fluids of high ionic strength.

The creation of contour maps was achieved by linear interpolation using the Scientific Python (SciPy) library. Scipy is an open source Python-based library commonly used for scientific and technical computing [45].

\section{Approach}

To specify the dedolomitization potential of gypsum-toanhydrite dehydration fluids it is essential to define the volume of fluid released as well as the calcium concentration of those fluids. The total dissolved calcium is referenced to as $\mathrm{Ca}$, to be inclusive of all aqueous species.

Taking molar volumes into consideration it can be calculated that $1 \mathrm{~m}^{3}$ of anhydrite may be formed due to the dehydration of $1.62 \mathrm{~m}^{3}$ of gypsum, releasing a total of $0.8 \mathrm{~m}^{3}$ of water [46]. This is equal to an overall volume increase of about $10 \%$.

The solubility of anhydrite in water mainly depends on salinity and temperature and to a lesser degree on pressure [47]. A simple PHREEQC batch model, where anhydrite is brought into solution at different temperatures $\left(10^{\circ} \mathrm{C}-70^{\circ} \mathrm{C}\right)$ and different salinities ( 0.0 moles $/ \mathrm{kgw}-7.0 \mathrm{moles} / \mathrm{kgw})$, shows that an increase in temperature decreases the solubility of anhydrite and that an increase in salinity increases the solubility of anhydrite (Figure 4). The influence of salinity on solubility is higher for low temperatures and decreases slightly at high temperatures. Solubilities displayed in Figure 4 are in good agreement with the batch modelling results of Li and Duan [47] and experimental data by Kushnir [48]. The Ca concentration of fluids released by gypsum 


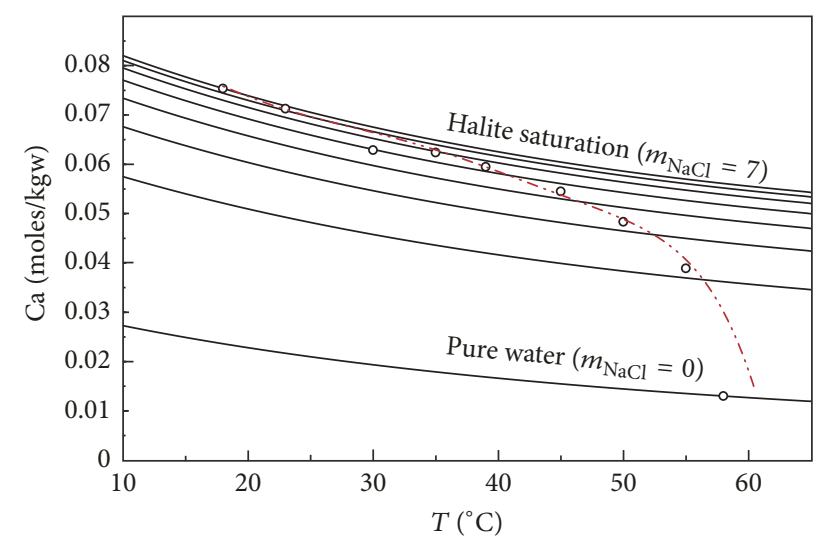

Figure 4: Simple PHREEQC batch model which predicts the solubility of anhydrite as a function of temperature and salinity at one atmosphere pressure. Each isoline represents an increase of 1 mole in salinity starting with 0 moles at the lowermost part of the figure. The points represent the anhydrite solubility under dehydration conditions as specified by Hardie [36].

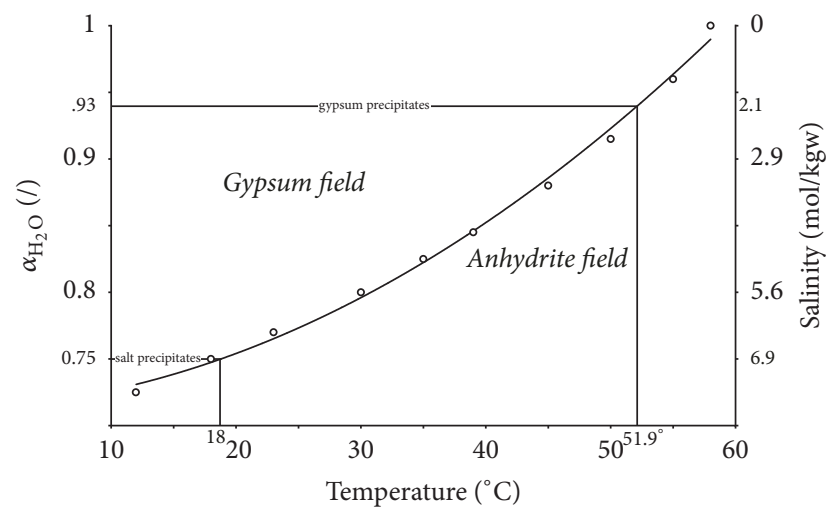

FIGURE 5: Gypsum and anhydrite stability fields depending on temperature and water activity (salinity) of the fluids involved (modified after Jowett et al. [32] with data from [Hardie [36]]).

dehydration therefore depends on temperature and salinity during the conversion into anhydrite.

A plot derived from the experimental data provided by Hardie [36] yielded transition temperatures of about $58^{\circ} \mathrm{C}$ in pure water. If the pore fluid composition approaches halite saturation the temperature needed for gypsum-to-anhydrite conversion drops to approximately $18^{\circ} \mathrm{C}$ (Figure 5).

The highest $\mathrm{Ca}$ concentrations are reached when gypsumto-anhydrite dehydration occurs at high salinities and therefore at shallow burial depths and low temperatures (Figure 4).

Compared to salinity and temperature, the effect of pressure on the gypsum-to-anhydrite conversion is small [49]. MacDonald [50] calculated a theoretical decrease of one degree in conversion temperature for an increase in pressure of 39.45 bar (3.945 MPa) under hydrostatic conditions. Assuming an average bulk density of $2.3 \mathrm{~g} / \mathrm{cm}^{3}$ about $175 \mathrm{~m}$ of overburden would be necessary to decrease the conversion temperature by $1^{\circ} \mathrm{C}$.

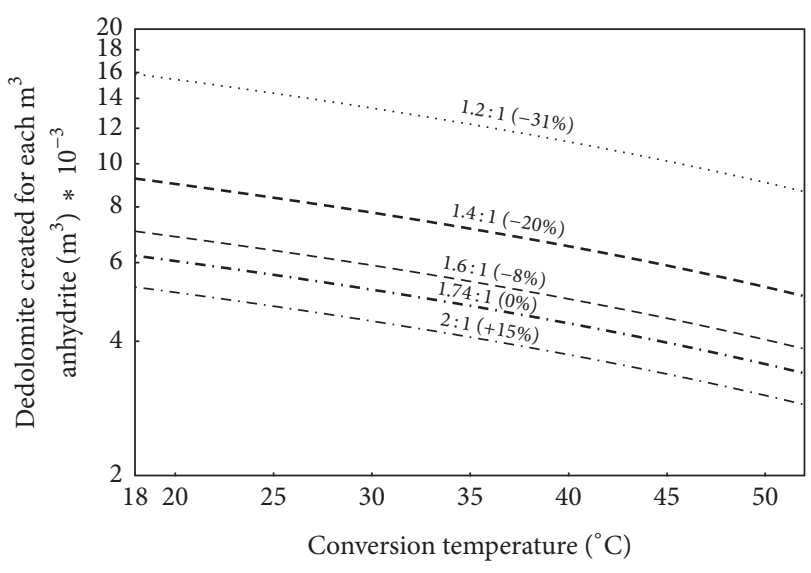

FIGURE 6: Dedolomitization potential of the fluids released during the creation of $1 \mathrm{~m}^{3}$ of anhydrite as a function of conversion temperature and dedolomitization reaction stoichiometry as well as the associated change in solid volume in brackets. With higher conversion temperatures, the amount of $\mathrm{Ca}$ within the conversion fluid decreases and therefore the dedolomitization potential decreases as well. A lower reaction stoichiometry increases the dedolomitization potential due to the decreasing amount of excess Ca needed during each reaction step. The reaction stoichiometry of $1.74: 1$ marks the transition from a porosity creating (lower values) to a porosity destructive process (higher values).

The amount of Ca necessary to replace 1 mole of dolomite with calcite depends on the reaction stoichiometry. The commonly denoted dedolomite reaction assumes that 1 mole of dolomite gets replaced by 2 moles of calcite (R1, Evamy [6]), consuming 1 mole of $\mathrm{Ca}$. The dedolomitization potential increases exponentially for lower reaction stoichiometries, since less and less external calcium is needed for the replacement reaction (Figure 6). Due to the larger molar volume of 2 moles of calcite as compared to 1 mole of dolomite this reaction leads to an increase in solid volume and thereby a decrease in porosity (Figure 6). Dedolomitization may however also lead to the creation [11, 51, 52] or the preservation of porosity [6]. A pseudomorphic volume-pervolume replacement is defined by the reaction stoichiometry of $1.74: 1$ which is the ratio between the molar volume of dolomite and calcite. We stopped modelling at the arbitrary ratio of $1.2: 1$ to display the range and influence of reaction stoichiometry on the dedolomitization potential (Figure 6). However, most dedolomite observed is associated with a loss or preservation of porosity rather than the increase thereof $[6,7,53]$. To determine the reaction stoichiometry during dedolomitization it is necessary to quantify the porosity within the original dolomite and dedolomite. Petrographic study of stained thin-sections is best suited for this task since it allows for the differentiation between changes in porosity due to dedolomitization and other diagenetic processes. The resulting reaction stoichiometry can then be calculated with

$$
\mathrm{Rs}=\frac{M_{\mathrm{Dol}}}{M_{\mathrm{Cal}}} *\left(\frac{\left(\emptyset_{\mathrm{Dol}}-\emptyset_{\mathrm{Cal}}\right)}{\left(1-\emptyset_{\mathrm{Dol}}\right)}+1\right)
$$


where $M_{\text {Dol }}\left[\mathrm{cm}^{3} /\right.$ mole $]$ and $M_{\text {Cal }}\left[\mathrm{cm}^{3} /\right.$ mole] represent the molar volume of dolomite and calcite and $\emptyset_{\text {Dol }}$ and $\emptyset_{\text {Cal }}$ are equal to the porosity of dolomite and calcite expressed as decimal values.

The amount of dedolomite which is created $\left(\operatorname{Dd}_{\mathrm{cr}}\left[\mathrm{m}^{3}\right]\right)$ is then defined by

$$
\operatorname{Dd}_{\text {cr }}=\left(\frac{C_{a_{\text {fluid }}}}{\mathrm{Rs}-1}\right) * \mathrm{Rs} * V_{\text {Cal }} *\left(1+\emptyset_{\text {Cal }}\right),
$$

where $\mathrm{Ca}_{\text {fluid }}$ [mole] represents the total amount of $\mathrm{Ca}$ ions in solution, Rs [/] is defined by the reaction stoichiometry, $V_{\text {Cal }}$ $\left[\mathrm{m}^{3} /\right.$ mole] represents the molar volume of calcite, and $\emptyset_{\text {Cal }}[/]$ is equal to the porosity of the resulting dedolomite expressed as decimal value. The volume increases, if the resulting dedolomite contains residual porosity. This value has to be defined beforehand by means of petrographic observations, well $\log$ analysis, and/or petrophysical measurements.

The resulting dedolomitization potential is relatively low with values ranging between $6.2 * 10^{-3} \mathrm{~m}^{3}$ and $2.8 * 10^{-3} \mathrm{~m}^{3}$ of dedolomite created for each $\mathrm{m}^{3}$ of anhydrite, assuming that reaction stoichiometries vary from 1.74 to 2 (Figure 6). Correspondingly $126 \mathrm{~m}^{3}$ to $278 \mathrm{~m}^{3}$ of dehydration fluids is needed to create $1 \mathrm{~m}^{3}$ of calcite, assuming a $100 \%$ effective process.

\section{Case Study: Zechstein-2-Carbonates}

To test the dedolomitization potential of gypsum-to-anhydrite conversion fluids we apply the aforementioned considerations regarding anhydrite solubility at the point of dehydration onto the $\mathrm{Ca} 2$ dedolomite system. To present a stronger argument we assume boundary conditions under which dedolomitization is favored. This implies low temperatures and high salinities during a shallow burial conversion (Figure 4). This assumption follows existing interpretations of very shallow conversion depths $[54,55]$ as well as shallow dedolomitization depths [9].

For the purpose of this model we estimate the conversion depth to be $50 \mathrm{~m}$. Note that we do not propose that this depth is the real conversion depth but rather the depth at which the conversion fluid would have yielded a high dedolomitization potential.

The temperature for conversion at such low depths is dictated by the sea surface temperature during the late Permian, which is estimated to be $26^{\circ} \mathrm{C}$ [56]. The salinity necessary to achieve gypsum-to-anhydrite conversion at such temperatures is equal to $6.1 \mathrm{~m}_{\mathrm{NaCl}}$ (Figure 5). Since there is hardly any overburden at such low depths the pressure effect on conversion temperature and anhydrite solubility can be neglected. The solubility of anhydrite at the salinity and temperature specified above is equal to 83 moles per $\mathrm{kg}$ of water. This is equal to 65.3 moles per $\mathrm{m}^{3}$ of anhydrite created during dehydration.

The reaction stoichiometry was calculated with average porosities of dolomite (16.9\%) and calcite $(3.8 \%)$ for the Zechstein-2-Carbonates in NW Germany as determined by Biehl et al. [2]. The resulting reaction stoichiometry is equal to about $2: 1$. This fits the observed connection between dedolomitization and a near-complete loss of porosity within the study area [23].

Taking the above described boundary conditions into consideration we estimate that $5 * 10^{-3} \mathrm{~m}^{3}$ of dedolomite may be produced for each $\mathrm{m}^{3}$ of anhydrite. This dedolomitization potential can then be applied onto the selected wells to determine if the gypsum-to-anhydrite conversion fluids represent a sufficient calcium source within each well. The amount of calcite in each well is determined by multiplying the calcitedolomite ratio with the thickness of the $\mathrm{Ca} 2$ of the selected well (Table 1).

The well data provided by EMPG includes the thickness of the over- and underlying anhydrite sequences (A2 and A1, resp.). This value is then multiplied with the dedolomitization potential for the selected boundary conditions defined in this section. The result represents the amount of dedolomite which can potentially be created by the fluids released during gypsum-to-anhydrite conversion for each well. This number is then compared with the actual amount of dedolomite observed in each well to estimate the amount of dedolomite which is accounted for by the gypsum-to-anhydrite dehydration fluids (Table 1), as well as the spatial distribution of this ratio (Figure 7).

For the vast majority of the wells the dehydration fluids represent an insufficient $\mathrm{Ca}$ source. On the slope, where massive amounts of dedolomite can be found, the dehydration fluids account for less than $1 \%$ of the encountered dedolomite (Table 1). From slope to platform, a decrease of dedolomite content is observed to correlate with a decrease in insufficiency of the dehydration fluids. Five wells did not contain any dedolomite and were mainly included to better demonstrate the spatial distribution of dedolomite within the study area (Figure 7).

Due to the simplistic set-up of the model the results include several uncertainties. For once we do not account for horizontal migration of conversion fluids. It has been shown that the wells studied from the platform environment of deposition contain low to no amounts of calcite (Table 1). Therefore, conversion fluids should be locally overabundant. The migration of these fluids to the slope, where the volume of over- and underlying gypsum is insufficient, could lead to the additional input of $\mathrm{Ca}$. However, excess dedolomite of the platform is about two orders of magnitude smaller than unaccounted dedolomite in the upper portion of the slope (Table 1). Therefore, it appears unlikely that the redistribution of conversion fluids could be responsible for this discrepancy (Figure 7).

The transport of conversion fluids from source (A2 and A1) to sink (Ca2) is treated as a $100 \%$ effective process. This likely leads to an overestimation dedolomitization potential. For once, the conversion fluids may lose $\mathrm{Ca}$ along the migration path due to processes other than dedolomitization. One possible additional sink for calcium is the cementation of the Ca2-carbonates with anhydrite, which Clark [9] has linked to the influx of dehydration fluids.

The assumption that the total amount of fluids created during dehydration migrates into the $\mathrm{Ca} 2$ may also be flawed. The A2 is overlain by thick sequences of impermeable salt. 
TABLE 1: List of wells used for the estimation of the dedolomitization potential of gypsum dehydration within the study area. The amount of dedolomite within each well which is accounted for by the dehydration fluids or pressure solution is expressed as percentage and in absolute values. Values in bold indicate an insufficiency of dedolomitizing fluids while italic values represent overabundance of dedolomitizing fluids.

\begin{tabular}{|c|c|c|c|c|c|c|}
\hline \multirow{2}{*}{ Well number } & \multicolumn{3}{|c|}{ Thickness [m] } & \multirow{2}{*}{$\begin{array}{c}\text { Dedolomite content (Ca2) } \\
{[\%] /[m]}\end{array}$} & \multirow{2}{*}{$\begin{array}{l}\text { Dedolomite accounted for, } \\
\text { dehydration }[\%] /[\mathrm{m}]\end{array}$} & \multirow{2}{*}{$\begin{array}{l}\text { Dedolomite accounted for, } \\
\text { pressure solution }[\%] /[\mathrm{m}]\end{array}$} \\
\hline & $\mathrm{A} 2$ & $\mathrm{Ca} 2$ & $\mathrm{~A} 1$ & & & \\
\hline (1) & 6.5 & 71.5 & 41 & $43.7 / 31.2$ & $0.8 / \mathbf{0 . 3}$ & $82.8 / 25.6$ \\
\hline (2) & 5.5 & 82 & 40.8 & $98 / 80.4$ & $0.3 / \mathbf{0 . 2}$ & $30.3 / 24.1$ \\
\hline (3) & 3 & 89.5 & 36.5 & $94.4 / 84.5$ & $0.2 / \mathbf{0 . 2}$ & $24.6 / 20.5$ \\
\hline (4) & 3 & 122 & 37.5 & $90.8 / 110.8$ & $0.2 / \mathbf{0 . 2}$ & $19.2 / 21.1$ \\
\hline (5) & 4 & 107.7 & 26.9 & $86.5 / 93.2$ & $0.2 / \mathbf{0 . 2}$ & $17.4 / \mathbf{1 6 . 1}$ \\
\hline (6) & 4 & 120 & 38 & $99 / 118.8$ & $0.2 / \mathbf{0 . 2}$ & $18.6 / 21.8$ \\
\hline (7) & 11.5 & 51.3 & 284.4 & $35 / 17.9$ & $8.6 / 1.5$ & $100 / 153.8$ \\
\hline (8) & 59.5 & 226.5 & 146.5 & $18.4 / 41.7$ & $2.6 / 1.1$ & $100 / 107.1$ \\
\hline (9) & 5 & 101.9 & 42.9 & $66.1 / 67.4$ & $0.4 / \mathbf{0 . 2}$ & $37.3 / 24.9$ \\
\hline (10) & 2.5 & 100.4 & 29.9 & $95.8 / 96.2$ & $0.2 / \mathbf{0 . 2}$ & $17.7 / \mathbf{1 6 . 8}$ \\
\hline (11) & 38.5 & 199.8 & 90.9 & $9.4 / 18.8$ & $3.6 / 0.7$ & $100 / 67.3$ \\
\hline (12) & 28.5 & 29.5 & 243.7 & $3.9 / 1.2$ & $100 / 1.4$ & $100 / 141.5$ \\
\hline (13) & 29.5 & 30.5 & 258.7 & $14.2 / 4.3$ & $34.6 / \mathbf{1 . 5}$ & $100 / 149.9$ \\
\hline (14) & 33 & 26 & 170 & $0 / 0$ & $100 / 1.1$ & $100 / 105.6$ \\
\hline (15) & 77.9 & 29 & 254.9 & $0 / 0$ & $100 / 1.7$ & $100 / 173.1$ \\
\hline (16) & 92 & 31 & 242.8 & $0 / 0$ & $100 / 1.7$ & $100 / 174.1$ \\
\hline (17) & 32.5 & 32.5 & 265.9 & $0 / 0$ & $100 / 1.5$ & $100 / 155.2$ \\
\hline (18) & 26.9 & 23 & 213.5 & $0 / 0$ & $100 / 1.2$ & $100 / 125.0$ \\
\hline
\end{tabular}

It is therefore reasonable to assume that fluids migrated dominantly into the underlying $\mathrm{Ca} 2$. This is, however, not applicable to the A1, which overlies the Zechstein Limestone ("Werra-Karbonat," Ca1) (Figure 2). It has to be assumed that some amount of the dehydration fluids migrated downwards into the Cal, therefore being unavailable for dedolomitization of the $\mathrm{Ca} 2$. This statement increases in relevance since the A1 is up to 20 times thicker than the A2 within the study area, thus contributing higher amounts of conversion fluids to the model (Table 1). Due to similar reasons it is possible that the assumed salinity $\left(m_{\mathrm{NaCl}}=6.1\right)$ is not representative for the A1, which was succeeded by a carbonate system, dominated by fluids of marine composition.

We propose the following processes as a potential alternative Ca source for the pervasive dedolomitization of the Zechstein-2-Carbonates:

\section{(i) Gypsum mush compaction}

(ii) Pressure solution of gypsum and/or anhydrite

At surface, gypsum can accumulate as a highly porous mush with reported porosities ranging between $30 \%$ and $67 \%$ [57, 58] and $\mathrm{Ca}$ pore fluid saturations being as high as 0.035 moles/liter [57]. During the early stages of compaction these fluids could be expelled into the $\mathrm{Ca} 2$ carbonates, thereby introducing fluids rich in $\mathrm{Ca}$ into the system [59]. However, since the volume and $\mathrm{Ca}$ saturation of these fluids range within the same order of magnitude as those which are produced during gypsum dehydration it appears unlikely that this process introduced enough $\mathrm{Ca}$ into the $\mathrm{Ca} 2$ system to explain the large amounts of dedolomite observed (Figure 4).
Another possible calcium source could be the dissolution of anhydrite or gypsum due to pressure. Bäuerle et al. [55] reported a high abundance of stylolites within the A3 "Hauptanhydrit" (Main Anhydrite) of the Gorleben salt dome in northern Germany. Assuming a volume loss of 26\% [55] it is possible to calculate the amount of $\mathrm{Ca}$ which could potentially be introduced into the $\mathrm{Ca} 2$ of the study area by a similar stylolitization of the A1 and A2. Like dehydration, the amount of dedolomite which can be produced due to pressure solution is then primarily defined by the reaction stoichiometry as well as the porosity within the dedolomite.

A simulation run with equal boundary conditions compared to those proposed for the dehydration fluids reveals that the dedolomitization potential of pressure solution is substantially higher than that of dehydration fluids (Figure $7(\mathrm{c})$ ). The platform, where dedolomite is rare and anhydrite thicknesses are rather large, displays a dedolomitization potential which greatly exceeds demand. Towards the upper and middle slope the model still fails to predict the large amounts of dedolomite encountered. However, the redistribution of excess $\mathrm{Ca}$-rich fluids predicted for the platform could explain the large quantities of dedolomite observed within the upper and middle slope.

\section{Conclusion}

Geochemical batch modelling and mass balance constraints reveal that fluids derived from gypsum-to-anhydrite dehydration represent a potential Ca source for dedolomitization during burial. The amount of solid dedolomite created 


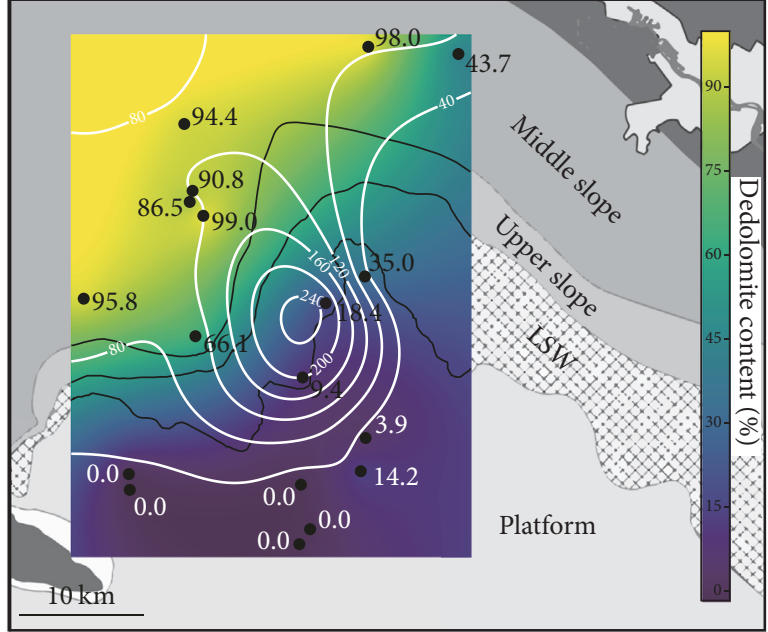

(a)

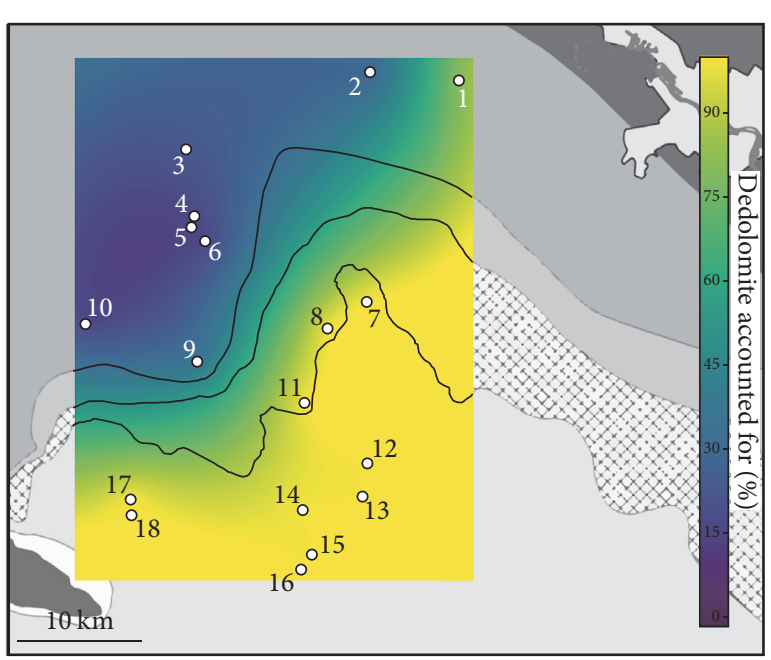

(c)

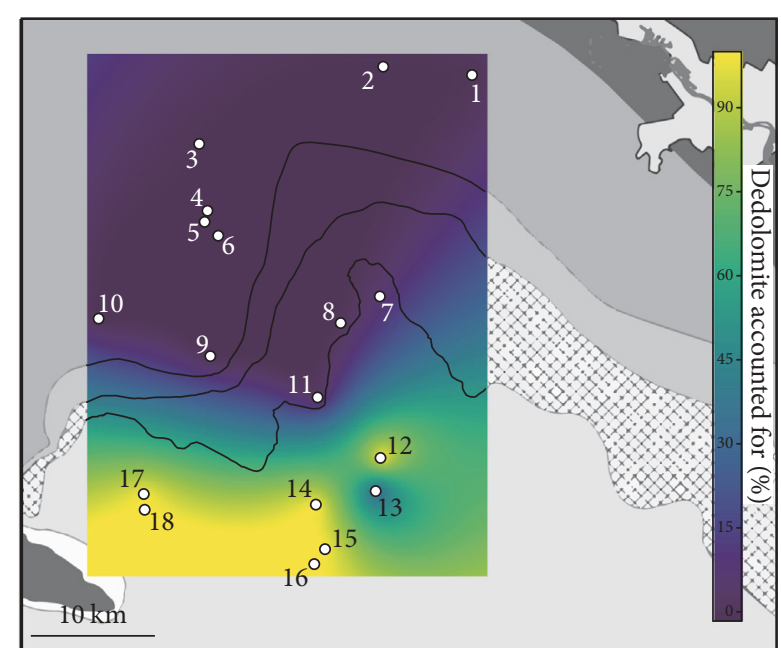

(b)

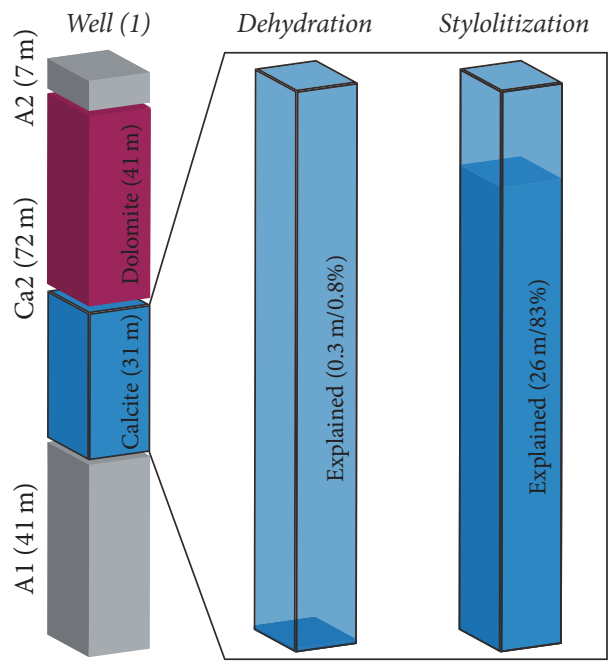

(d)

Figure 7: (a) The contour map displays the color coded percentage (0-100\%) of dedolomite on the Ca2 bulk sediment within the study area. Values are interpolated from the well data provided by EMPG and annotated at each well. White contour lines represent the distribution of thickness of the $\mathrm{Ca} 2$ within the study area. $(\mathrm{b}+\mathrm{c})$ The contour maps represent the discrepancy between the dedolomitization potential of the calculated dehydration fluids (b) and fluids released due to pressure solution (c) and the actual observed amount of dedolomite. All contour maps overlie the paleogeography of the Ca2 in northern Germany during late Permian times (modified after Strohmenger et al. [1]). (d) Dedolomite content and dedolomitization potential of dehydration and pressure solution fluids were determined on a well-by-well basis (here Well (1)) and then interpolated between the wells to create the contour maps in (b) and (c).

for each $\mathrm{m}^{3}$ of anhydrite ranges between $6.2 * 10^{-3}$ and $2.8 * 10^{-3} \mathrm{~m}^{3}$ depending on the temperature, salinity, and reaction stoichiometry (1.74 to 2) during dedolomitization, with highest values being achieved at low temperatures and high salinities. Dedolomitization due to gypsum-toanhydrite dehydration is therefore most effective during shallow burial.

However, the modelling results of the Zechstein-2Carbonate case study challenge the classical dedolomitization model that has been applied for diagenetic reservoir models of the Ca2 across the Southern Permian Basin. Mass balance constraints show that additional calcium sources are necessary, to account for the large amounts of observed dedolomite. Considering that our calculations represent a best-case scenario it may be concluded that gypsum-toanhydrite dehydration is not capable of producing the vast amounts of dedolomite, which can be found within the study area and by extension the Ca2 of the Southern Permian Basin. Instead this research suggests the presence of additional sources of calcium, such as pressure solution within the A2 and Al sulfates. Further research is needed to shed light on the presence, magnitude, and distribution of pressure solution as well as the potential correlation with dedolomite distribution. 


\section{Conflicts of Interest}

The authors declare that there are no conflicts of interest regarding the publication of this paper.

\section{Acknowledgments}

The authors like to thank ExxonMobil Production Deutschland $\mathrm{GmbH}$ (EMPG) for granting the right to publish the results of this study. Furthermore, they are grateful to EMPG for providing the large quantities of data used within this study. Sven Fellmin is acknowledged for the determination of calcite-dolomite ratios within the studied wells. The authors deeply thank Christian Strohmenger and Franz Brauckmann for insightful discussions and thoughts.

\section{References}

[1] C. Strohmenger, M. Antonini, G. Jäger, K. Rockenbauch, and C. Strauss, "Zechstein 2 carbonate reservoir facies distribution in relation to zechstein sequence stratigraphy (upper Permian, northwest Germany): An integrated approach," Bulletin des Centres de Recherches Elf Exploration Production, vol. 20, no. 1, pp. 1-35, 1996.

[2] B. C. Biehl, L. Reuning, J. Schoenherr, A. Lewin, M. Leupold, and P. A. Kukla, "Do CO2-charged fluids contribute to secondary porosity creation in deeply buried carbonates?" Marine and Petroleum Geology, vol. 76, pp. 176-186, 2016.

[3] B. C. Biehl, L. Reuning, J. Schoenherr, V. Lüders, and P. A. Kukla, "Impacts of hydrothermal dolomitization and thermochemical sulfate reduction on secondary porosity creation in deeply buried carbonates: A case study from the Lower Saxony Basin, northwest Germany," AAPG Bulletin, vol.100, no. 4, pp. 597-621, 2016.

[4] H. Füchtbauer, "Fazies, Porosität und Gasinhalt der Karbonatgesteine des norddeutschen Zechsteins," Zeitschrift der Deutschen Geologischen Gesellschaft, vol. 114, pp. 484-531, 1962.

[5] H. Quester, "Petrographie des erdgashöffigen Hauptdolomits im Zechstein 2 zwischen Weser und Ems," Zeitschrift der Deutschen Geologischen Gesellschaft, vol. 114, no. 3, pp. 461-482, 1964.

[6] B. D. Evamy, "Dedolomitization And The Development Of Rhombohedral Pores In Limestones," Journal of Sedimentary Petrology, vol. 37, no. 4, pp. 1204-1215, 1967.

[7] C. Ayora, C. Taberner, M. W. Saaltink, and J. Carrera, "The genesis of dedolomites: A discusion based on reactive transport modeling," Journal of Hydrology, vol. 209, no. 1-4, pp. 346-365, 1998.

[8] K. de Groot, "Experimental Dedolomitization," SEPM Journal of Sedimentary Research, vol. 37, no. 4, pp. 1216-1220, 1967.

[9] D. N. Clark, "The diagenesis of Zechstein carbonate sediments," Contr. Sedimentology, vol. 9, pp. 167-203, 1980.

[10] W. S. Al-Hashimi and J. E. Hemingway, "Recent dedolomitization and the origin of the rusty crusts of Northumberland," Journal of Sedimentary Research, vol. 43, no. 1, pp. 82-91, 1973.

[11] B. H. Purser, "Early diagenesis and the preservation of porosity in jurassic limestones," Journal of Petroleum Geology, vol. 1, no. 2, pp. 83-94, 1978.

[12] J. M. Budai, K. C. Lohmann, and R. M. Owen, "Burial dedolomite in the Mississippian Madison Limestone, Wyoming and Utah Thrust Belt (USA)," Journal of Sedimentary Petrology, vol. 54, no. 1, pp. 276-288, 1984.

[13] K. S. Woo and C. H. Moore, "Burial dolomitization and dedolomitization of the late Cambrian Wagok Formation, Yeongweol, Korea," Carbonates and Evaporites, vol. 11, no. 1, pp. 104-112, 1996.

[14] R. Wierzbicki, J. J. Dravis, I. Al-Aasm, and N. Harland, "Burial dolomitization and dissolution of Upper Jurassic Abenaki platform carbonates, Deep Panuke reservoir, Nova Scotia, Canada," AAPG Bulletin, vol. 90, no. 11, pp. 1843-1861, 2006.

[15] C. Cai, W. He, L. Jiang, K. Li, L. Xiang, and L. Jia, "Petrological and geochemical constraints on porosity difference between Lower Triassic sour- and sweet-gas carbonate reservoirs inthe Sichuan Basin," Marine and Petroleum Geology, vol. 56, pp. 3450, 2014.

[16] L.-C. Escorcia, E. Gomez-Rivas, L. Daniele, and M. Corbella, "Dedolomitization and reservoir quality: Insights from reactive transport modelling," Geofluids, vol. 13, no. 2, pp. 221-231, 2013.

[17] L. S. Land and D. R. Prezbindowski, "The origin and evolution of saline formation water, Lower Cretaceous carbonates, southcentral Texas, U.S.A.", Journal of Hydrology, vol. 54, no. 1-3, pp. 51-74, 1981.

[18] N. Rameil, "Early diagenetic dolomitization and dedolomitization of Late Jurassic and earliest Cretaceous platform carbonates: A case study from the Jura Mountains (NW Switzerland, E France)," Sedimentary Geology, vol. 212, no. 1-4, pp. 70-85, 2008.

[19] P. Huttel, Das Straßfurt-Karbonat (Ca2) in Süd-Oldenburg Fazies und Diagenese eines Sediments am Nordhang der HunteSchwelle, Geologische Institute, Universität Göttingen, 1987.

[20] S. Mausfeld, Der Plattformrand des Strassfurtkarbonats (Ca2) südlich von Oldenburg: Sedimentologie, Fazies und Diagenese, Fachbereich Geowissenschaften, Phillips Universität, Marburg, Germany, 1987.

[21] D. V. D. Baan, "Zechstein reservoirs in The Netherlands," Geological Society, London, Special Publications, vol. 50, pp. 379398, 1990.

[22] T. M. Peryt and P. A. Scholle, "Regional setting and role of meteoric water in dolomite formation and diagenesis in an evaporite basin: Studies in the Zechstein (Permian) deposits of Poland," Sedimentology, vol. 43, no. 6, pp. 1005-1023, 1996.

[23] K. M. Love, C. Strohmenger, A. Woronow, and K. Rockenbauch, "Predicting reservoir quality using linear regression models and neural networks," AAPG Memoire, no. 69, pp. 47-60, 1997.

[24] P. Huttel and S. Mausfeld, "Diagenesis of a carbonate member of an evaporitic cycle: The Strassfurt carbonate formation (Ca2) of South Oldenburg NW Germany," Zbl. Geol. Paläont, vol. 1, no. 4, pp. 1073-1090, 1991.

[25] A. Below, Fazies- und geochemische Diagenesestudie im Zechstein 2-Karbonat (Ca2) Nordwestdeutschland, Geol. Paläont. Inst., University of Kiel, 1992.

[26] S. N, I. Steinhoff, and S. Nöth, Diageneseentwicklung des Ca2 (Staßfurt-Karbonat) unter dem Aspekt der Thermochemischen Sulfatreduktion, BEB, Hannover, Germany, 1995.

[27] T. J. A. Reijers, “Sedimentology and diagenesis as 'hydrocarbon exploration tools' in the Late Permian Zechstein-2 Carbonate Member (NE Netherlands)," Geologos, vol. 18, no. 3, pp. 163-195, 2012.

[28] T. M. Peryt, M. C. Geluk, A. Mathiesen, J. Paul, and K. Smith, "Zechstein," in Petroleum Geological Atlas of the Southern Permian Basin Area, J. C. Doornebal and A. G. Stevenson, Eds., EAGE Publications, Houten, Netherlands, 2010. 
[29] R. Botz and G. Muller, "Mineralogie, Petrographie, anorganische Geochemie und Isotopen- Geochemie der Karbonatgesteine des Zechstein 2.," Geologisches Jahrbuch, Reihe D, vol. 47, pp. 3-112, 1981.

[30] B. P. Tissot and D. H. Welte, Petroleum Formation and Occurence, Springer-Verlag, 1984.

[31] E.-A. Zen, "Solubility measurements in the system CaSO4$\mathrm{NaCL}-\mathrm{H} 2 \mathrm{O}$ at $35 \circ, 50 \circ$, and $70 \circ$ cand one atmosphere pressure," Journal of Petrology, vol. 6, no. 1, pp. 124-164, 1965.

[32] E. C. Jowett, L. M. Cathles III, and B. W. Davis, "Predicting depths of gypsum dehydration in evaporitic sedimentary basins," The American Association of Petroleum Geologists Bulletin, vol. 77, no. 3, pp. 402-413, 1993.

[33] J. K. Warren, "Chapter 2 Sulfate Dominated Sea-Marginal and Platform Evaporative Settings:: Sabkhas and Salinas, Mudflats and Salterns," Developments in Sedimentology, vol. 50, no. C, pp. 69-187, 1991.

[34] I. Steinhoff and C. Strohmenger, "Zechstein 2 carbonate platform subfacies and grain-type distribution (Upper Permian, Northwest Germany)," Facies, no. 35, pp. 105-132, 1996.

[35] C. Strohmenger and C. Strauss, "Sedimentology and palynofacies of the Zechstein 2 Carbonate (Upper Permian, Northwest Germany): Implications for sequence stratigraphic subdivision," Sedimentary Geology, vol. 102, no. 1-2, pp. 55-77, 1996.

[36] L. A. Hardie, "The Gypsum-Anhydrite Equilibrium At One Atmosphere Pressure," American Mineralogist, vol. 52, 1967.

[37] Y. Maystrenko, U. Bayer, H.-J. Brink, and R. Littke, “The Central European basin system-an overview," in Dynamics of complex intracontinental basins, pp. 16-34, Springer, 2008.

[38] B. Bruns, R. di Primio, U. Berner, and R. Littke, "Petroleum system evolution in the inverted Lower Saxony Basin, northwest Germany: A 3D basin modeling study," Geofluids, vol. 13, no. 2, pp. 246-271, 2013.

[39] F. Strozyk, L. Reuning, M. Scheck-Wenderoth, and T. D, “The Tectonic History of the Zechstein Basin in the Netherlands and Germany," in Permo-Triassic Salt Provinces of Europe, North Africa and the Atlantic Margins: Tectonic and Hydrocarbon Potential, pp. 221-241, Elsevier, Amsterdam, Netherlands, 2017.

[40] J. C. M. Taylor, “Upper permian-zechstein," Petroleum Geology of the North Sea: Basic Concepts and Recent Advances: Fourth Edition, pp. 174-211, 2009.

[41] B. C. Biehl, L. Reuning, F. Strozyk, and P. A. Kukla, "Origin and deformation of intra-salt sulphate layers: An example from the Dutch Zechstein (Late Permian)," International Journal of Earth Sciences, vol. 103, no. 3, pp. 697-712, 2014.

[42] C. Strohmenger, E. Voigt, and J. Zimdars, "Sequence stratigraphy and cyclic development of Basal Zechstein carbonate Evaporite deposits with emphasis on Zechstein 2 off-platform carbonates (Upper Permian, Northeast Germany)," Sedimentary Geology, vol. 102, no. 1-2, pp. 33-54, 1996.

[43] S. Mausfeld and P. Huttel, "Facies development on a prograding ramp: The Strassfurt carbonate formation (Ca2) of south Oldenburg (NW-Germany)," Zbl. Geol. Paläont, vol. 1, no. 4, pp. 10571072, 1991.

[44] D. L. Parkhurst and C. A. J. Appelo, "Description of input and examples for PHREEQC version 3a computer program for speciation, batch-reaction, one-dimensional transport, and inverse geochemical calculations," US geological survey techniques and methods, vol. 6, 2013.

[45] J. E. Oliphant and P. Peterson, SciPy: Open Source Scientific Tools for Python, 2001, http://www.scipy.org/.
[46] J. R. Smyth and T. C. McCormick, "Crystallographic data for minerals," in Mineral Physics \& Crystallography: A Handbook of Physical Constants, vol. 2 of AGU Reference Shelf, pp. 1-17, American Geophysical Union, Washington, D. C., USA, 1995.

[47] J. Li and Z. Duan, "A thermodynamic model for the prediction of phase equilibria and speciation in the $\mathrm{H}_{2} \mathrm{O}-\mathrm{CO}_{2}-\mathrm{NaCl}$ $\mathrm{CaCO}_{3}-\mathrm{CaSO}_{4}$ system from 0 to $250 \circ \mathrm{C}, 1$ to 1000 bar with $\mathrm{NaCl}$ concentrations up to halite saturation," Geochimica et Cosmochimica Acta, vol. 75, no. 15, pp. 4351-4376, 2011.

[48] J. Kushnir, "The partitioning of seawater cations during the transformation of gypsum to anhydrite," Geochimica et Cosmochimica Acta, vol. 46, no. 3, pp. 433-446, 1982.

[49] D. Freyer and W. Voigt, "Crystallization and Phase Stability of CaSO 4 and CaSO 4 - Based Salts," Monatshefte für Chemie, vol. 134, no. 5, pp. 693-719, 2003.

[50] G. J. MacDonald, "Anhydrite-gypsum equilibrium relations," American Journal of Science, vol. 251, no. 12, pp. 884-898, 1953.

[51] B. H. Purser, "Dedolomite porosity and reservoir properties of Middle Jurassic carbonates in the Paris Basin, France," in Carbonate Petroleum Reservoirs, pp. 341-355, Springer, 1986.

[52] J. C. Cañaveras, S. Sánchez-Moral, J. P. Calvo, M. Hoyos, and S. Ordóñez, "Dedolomites associated with karstification. An example of early dedolomitization in lacustrine sequences from the tertiary Madrid Basin, Central Spain," Carbonates and Evaporites, vol. 11, no. 1, pp. 85-103, 1996.

[53] L. Reuning, J. Schoenherr, A. Heimann et al., "Constraints on the diagenesis, stratigraphy and internal dynamics of the surface-piercing salt domes in the Ghaba Salt Basin (Oman): A comparison to the Ara Group in the South Oman Salt Basin," GeoArabia, vol. 14, no. 3, pp. 83-120, 2009.

[54] R. Langbein, "The Zechstein sulphates: the state of the art," in The Zechstein facies in Europe, pp. 143-187, Springer, Heidelberg, Germany, 1987.

[55] G. Bäuerle, O. Bornemann, F. Mauthe, and D. Michalzik, "Origin of stylolites in upper permian Zechstein Anhydrite (Gorleben salt dome, Germany)," Journal of Sedimentary Research, vol. 70, no. 3, pp. 726-737, 2000.

[56] J. T. Kiehl and C. A. Shields, "Climate simulation of the latest Permian: Implications for mass extinction," Geology, vol. 33, no. 9, pp. 757-760, 2005.

[57] J. Kushnir, "Formation and early diagenesis of varved evaporite sediments in a coastal hypersaline pool.," Journal of Sedimentary Petrology, vol. 51, no. 4, pp. 1193-1203, 1981.

[58] G. Butler, P. M. Harris, and C. G. Kendall, Recent evaporites from the Abu Dhabi coastal flats, Special Publications of SEPM, 1982.

[59] J. Paul, "Gypsum domes and diapirs: Common features in the Zechstein (Upper Permian) of Germany," Geological Quarterly, vol. 58, no. 3, pp. 521-530, 2014. 

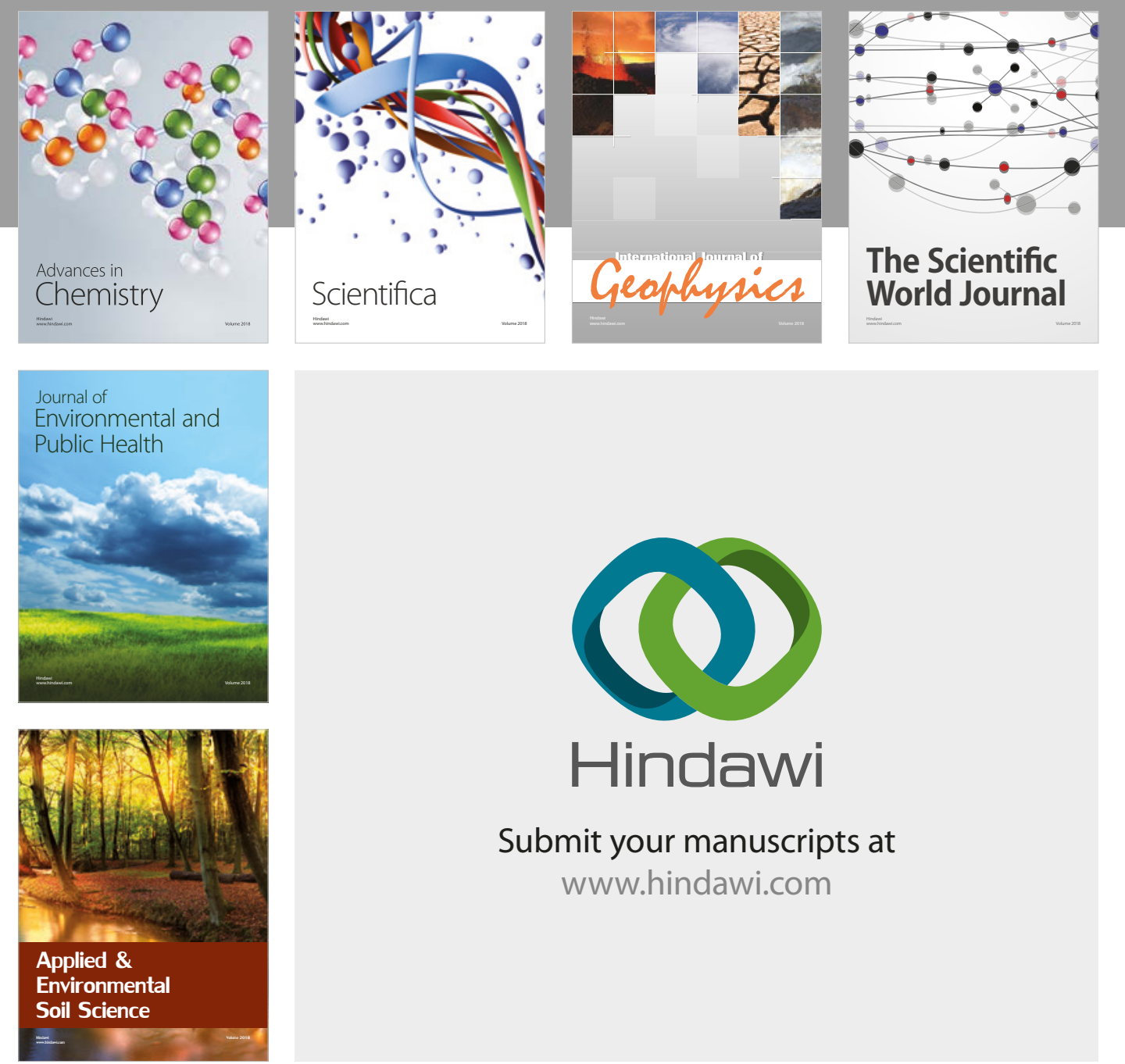

The Scientific

\section{World Journal}
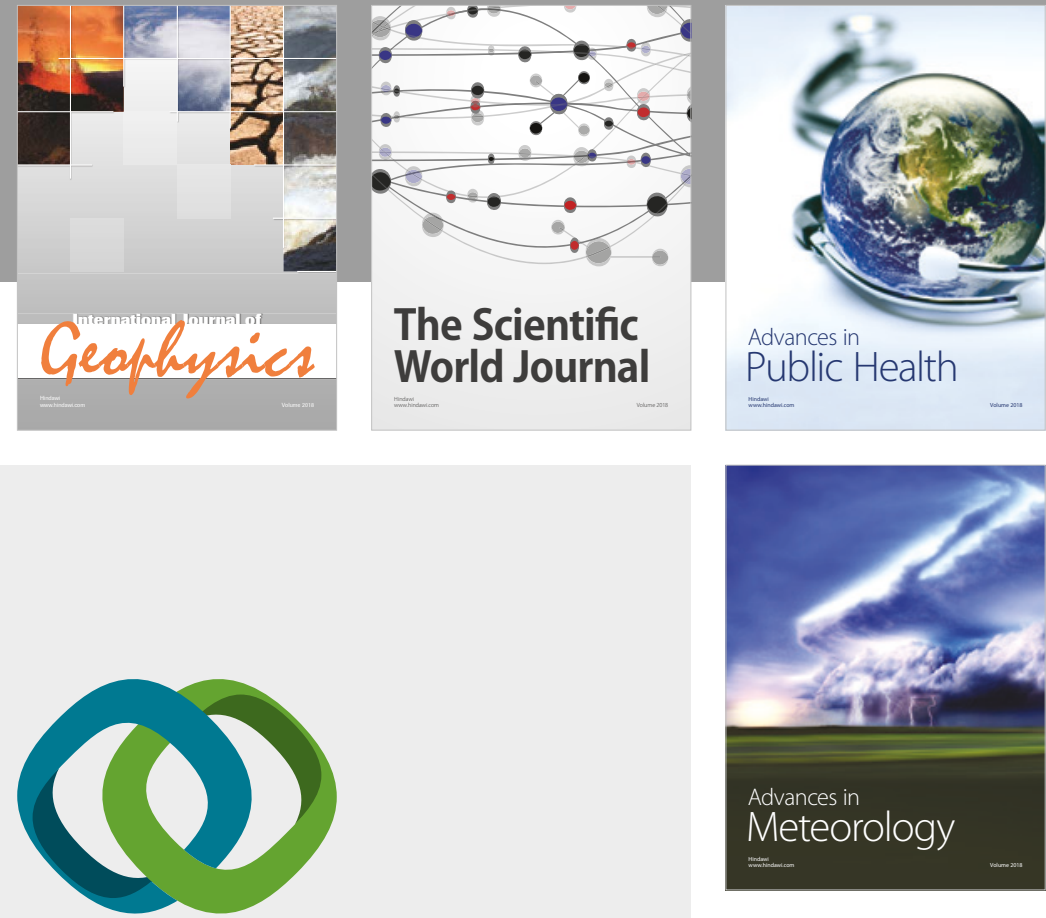

Advan

Public Health

\section{Hindawi}

Submit your manuscripts at

www.hindawi.com
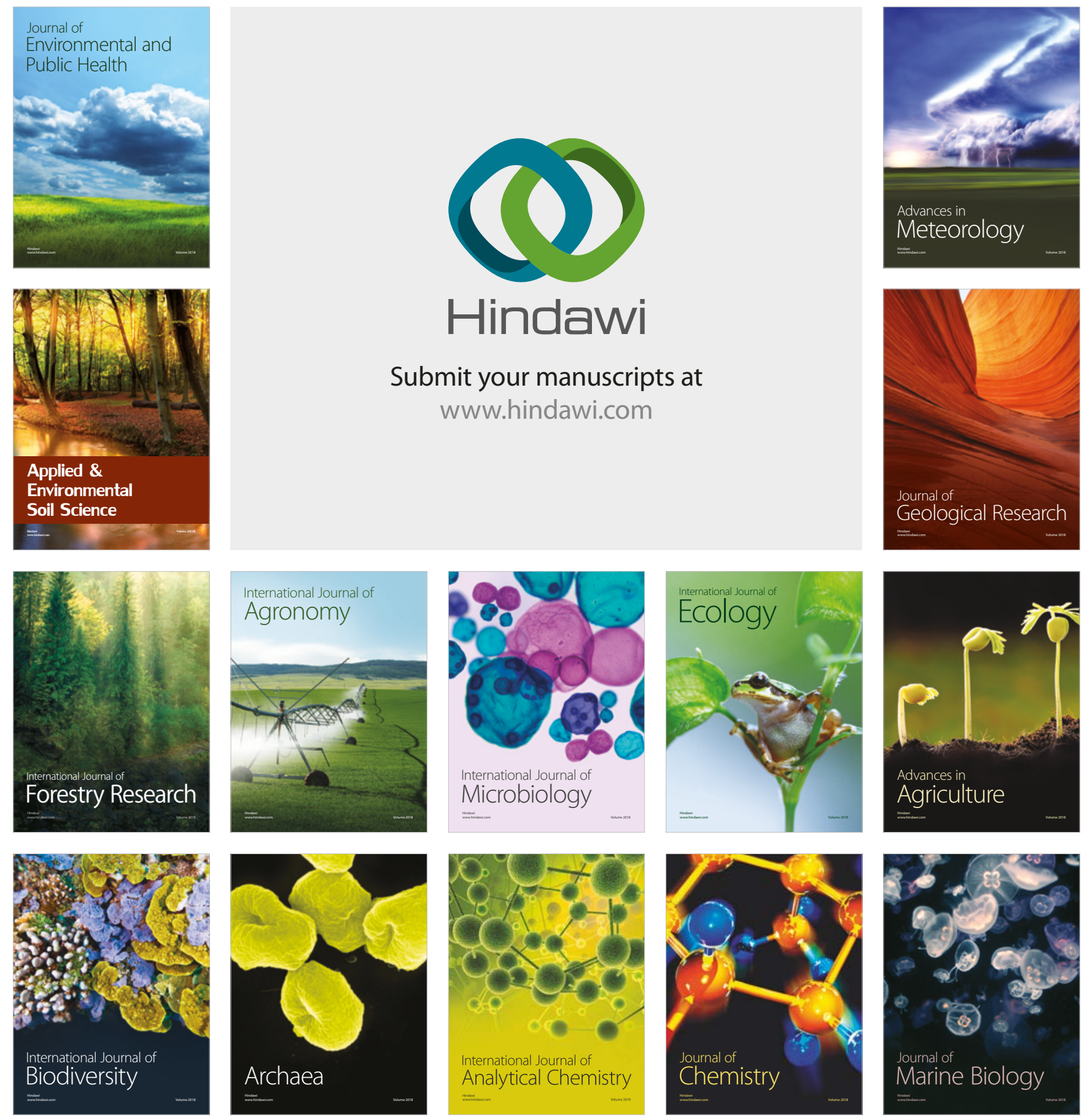